\title{
A breast cancer prediction model incorporating familial and personal risk factors
}

\author{
Jack Cuzick \\ From Familial Aspects of Cancer 2011 Research and Practice: A combined meeting of kConFab, Australian \\ Breast Cancer Family Study, Australian Colorectal Cancer Family Study, Australian Ovarian Cancer Study, \\ Family Cancer Clinics of Australia and New Zealand and kConFab \\ Kingscliff, Australia. 23-26 August 2011
}

Risk factors for breast cancer can be allocated to one of four groups:

1 Family History/genetic

2 Reproductive/hormonal

3 Proliferative benign breast disease

4. Mammographic density

These four factors have now been thoroughly studied and accurate quantitative estimates for the risk are now available for many of them. The most useful summary comes from the Oxford collaboration, which has now produced a series of papers estimating risk for individual factors. Less is known about the possible interaction between these factors and virtually nothing is known about how different factors influence the risk of different types of breast cancer e.g. oestrogen receptor positive versus negative tumours. Risk factors appear to be largely independent and this facilitates building a model to predict risk for individuals. Previous models have focused on either non-genetic factors [5] where important factors relating to genetic risk are not considered, or strictly familial factors in which the modifying effect of other factors is not included [4]. Mammographic density has not been included in any of these models, although it is currently the one risk factor with the largest population attributable risk [2]. Other authors have looked at combined models however [6].

Here we briefly review the main risk factors for breast cancer and describe our own model [7] and a computer programme for synthesizing the factors into an individual risk profile. The model has novel features in terms of combining family history data using segregation analysis with phenotypic factors using the proportional hazards model. Some comparisons between models will be made [1].

Published: 12 April 2012

References

1. Amir E, Freedman OC, Seruga B, Evans DG: Assessing women at high risk of breast cancer: a review of risk assessment models. J Natl Cancer Inst 2010, 102(10):680-91, Epub 2010 Apr 28.

2. Boyd NF, Byng JW, Jong RA, Fishell EK, Little LE, Miller AB, Lockwood GA, Tritchler DL, Yaffe MJ: Quantitative classification of mammographic densities and breast cancer risk: results from the Canadian National Breast Screening Study. J Natl Cancer Inst 1995, 87:670-5.

3. Boyd NF, Guo H, Martin $\sqcup$, Sun L, Stone J, Fishell E, Jong RA, Hislop G, Chiarelli A, Minkin S, Yaffe MJ: Mammographic density and the risk and detection of breast cancer. N Engl J Med 2007, 356(3):227-36.

4. Claus EB, Risch N, Thompson WD: Genetic analysis of breast cancer in the Cancer and Steroid Hormone Study. Am J Hum Genet 1991, 48:232-242.

5. Gail MH, Brinton LA, Byar DP, Corle DK, Green SB, Schairer C, Mulvihill JJ: Projecting individualized probabilities of developing breast cancer for white females who are being examined annually. J Natl Cancer Inst 1989, 81:1879-1886.

6. Tice JA, Cummings SR, Smith-Bindman R, Ichikawa L, Barlow WE, Kerlikowske $K$ : Using clinical factors and mammographic breast density to estimate breast cancer risk: development and validation of a new predictive model. Ann Intern Med 2008, 148(5):337-47.

7. Tyrer J, Duffy SW, Cuzick J: A breast cancer prediction model incorporating familial and personal risk factors. Stat Med 2004, 23:1111-1130.

doi:10.1186/1897-4287-10-S2-A29

Cite this article as: Cuzick: A breast cancer prediction model incorporating familial and personal risk factors. Hereditary Cancer in Clinical Practice 2012 10(Suppl 2):A29. 